BULLETIN Bulletin hispanique

HISPANIQUE Université Michel de Montaigne Bordeaux

115-1 | 2013

Poésie et société en Espagne : 1650-1750

\title{
Un autógrafo de fray Isidoro de Sevilla (1703): entre la predicación y la imprenta
}

Jaime Galbarro García

\section{(2) OpenEdition}

1 Journals

\section{Edición electrónica}

URL: http://journals.openedition.org/bulletinhispanique/2346

DOI: 10.4000/bulletinhispanique.2346

ISSN: $1775-3821$

\section{Editor}

Presses universitaires de Bordeaux

\section{Edición impresa}

Fecha de publicación: 1 junio 2013

Paginación: 49-74

ISBN: 978-2-86781-898-1

ISSN: 0007-4640

\section{Referencia electrónica}

Jaime Galbarro García, « Un autógrafo de fray Isidoro de Sevilla (1703): entre la predicación y la imprenta », Bulletin hispanique [En línea], 115-1 | 2013, Publicado el 01 junio 2016, consultado el 10 diciembre 2020. URL : http://journals.openedition.org/bulletinhispanique/2346 ; DOI : https://doi.org/ 10.4000/bulletinhispanique.2346 


\title{
Un autógrafo de fray Isidoro de Sevilla (1703): entre la predicación y la imprenta*
}

\author{
Jaime Galbarro García \\ Universidad de Sevilla - Grupo PASO
}

L'étude porte sur un autographe inconnu du capucin Isidore de Séville qui fut réutilisé à des fins diverses et qui apporte des éléments permettant de connaître ce que furent les premiers imprimés poétiques (aujourd'hui perdus) du patronage marial de la Divine Bergère.

Mots-clés : frère Isidore de Séville, poésie religieuse, XVIII ${ }^{e}$ siècle, autographe, imprimé.

Se lleva a cabo el estudio de un autógrafo desconocido (1703) del capuchino fray Isidoro de Sevilla que fue reutilizado con distintos fines y aporta datos para conocer cómo fueron los primeros impresos poéticos (hoy perdidos) sobre la advocación mariana de la Divina Pastora.

Palabras claves: fray Isidoro de Sevilla, poesía religiosa, siglo XVIII, autógrafo, imprenta.

The study focuses upon an unknown autograph of the Capuchin friar Isidore of Seville, reused for various purposes, and provides evidence of what were the first printed poetry books (now lost) on the Marian devotion of the Divine Shepherdess.

Keywords: friar Isidore of Seville, religious poems, XVIIIth, autograph, printing.

* Este trabajo se inscribe en las tareas del proyecto i+d El canon de la lírica áurea: constitución, transmisión e historiografía (III) (FFI2011-27449), financiado por el Ministerio de Economía y Competitividad. 


\section{INTRODUCCIÓN}

El 8 de septiembre de 1703 el capuchino fray Isidoro de Sevilla organizó por las calles de su ciudad una singular procesión encabezada por un estandarte con una imagen inédita de la Virgen. Este fraile sevillano había tenido la «ocurrencia» de presentar a la Virgen María con traje de pastora y hacerla venerar por los fieles con el rezo de una corona franciscana. Para entonces fray Isidoro de Sevilla tenía prácticamente ultimado un libro en el que exponía los argumentos que apoyaban su «idea predicable». Sin embargo, la impresión de esta obra, La Pastora Coronada, se retrasó hasta 1705, dos ańos durante los cuales el religioso siguió consolidando, entre los devotos y por las calles de Sevilla, esta nueva advocación de la Pastora de todas las Almas.

Durante el proceso de acopio de materiales para la preparación de la edición de La Pastora Coronada encontré un manuscrito en el Archivo Histórico Provincial de los Capuchinos de Andalucía que recoge las primeras composiciones poéticas que escribió el fraile para el rezo de la corona ${ }^{1}$. El valor de este testimonio autógrafo no reside tanto en los poemas como en el rico y complejo conjunto de datos derivados de la reutilización que se hizo de él. La descripción y análisis de su conformación permite reconstruir algunos de los primeros pasos que este capuchino dio en la predicación. Además, el manuscrito, fechado el 18 de noviembre de 1703, constituye hoy por hoy el testimonio escrito más antiguo de esta advocación religiosa, que ha tenido tan gran predicamento en el ámbito hispánico.

\section{Fray Isidoro de Sevilla y la advocación de la Divina Pastora}

Pese a la veneración y el fervor creciente que ha suscitado en los últimos tres siglos la advocación de la Divina Pastora, la figura histórica de fray Isidoro de Sevilla y su obra han sido poco atendidas. La primera biografía sobre el capuchino la escribió Heraclio de Villegas con el título El Apóstol mariano. Historial Poema y Exemplar Compendio de la admirable Vida y Singulares Virtudes del M. R. Ve. Pe . Fr. Ysidoro de Seuilla... Se trata de una extensa hagiografía acabada en 1751 y escrita en 849 octavas $^{2}$. Del mismo año son los sermones fúnebres compuestos por fray Miguel de Zalamea y fray Nicolás de Bilbao, quienes también aportan algunos datos sobre su vida ${ }^{3}$.

1. En la actualidad colaboro en las labores de ordenación e inventariado de la Biblioteca y el Archivo Histórico Provincial de los Capuchinos de Andalucía (AHPCA) bajo la dirección del historiador Antonio Valiente Romero. No todos los documentos aludidos en el presente artículo están ya inventariados, por lo que no se podrá aportar en todos los casos la signatura de localización.

2. Se conserva en una copia manuscrita fechada en 1890 que encargó el duque de T'Searcles como regalo para los capuchinos de Sevilla. AHPCA, lib. 647.

3. Vid. fray Miguel de Zalamea (O. F. M. Cap.), Sermón funebre de honras, que en las solemnes 
Durante los siglos XVIII y XIX proliferan las obras sobre la Divina Pastora, ya sea en forma de sermones, ensayos históricos que recapitulan cómo se instauró su veneración, crónicas de la orden, pliegos sueltos con versos para rezar la corona a la Virgen, etc. Todo ello ha estado acompañado desde el principio, y sin interrupción, por un intenso despliegue iconográfico de la Virgen con el atuendo pastoril ${ }^{4}$. Esta imagen, ya fijada por fray Isidoro de Sevilla en sus diversas obras, ha dado lugar a multitud de pinturas, esculturas, estandartes, azulejos, estampas, etc.

No obstante, hay que esperar al siglo XX para encontrar un paulatino interés por el fraile y la aparición de estudios históricos más completos sobre su advocación mariana. En este sentido destaca especialmente fray Juan Bautista de Ardales (O. F. M. Cap.), doctor en Sagrada Teología y ministro provincial durante cuatro trienios no consecutivos entre 1920-1937, quien intercedió ante el papa Benedicto XV para conseguir que en 1921 el título de Divina Pastora de las Almas fuera cotitular del convento de los capuchinos de Sevilla, junto con las santas mártires Justa y Rufina ${ }^{5}$. Con este motivo se organizaron una serie de celebraciones religiosas y un certamen literario con varios premios, uno de ellos a la mejor biografía presentada sobre fray Isidoro, que fue obtenido por fray Sebastián de Ubrique ${ }^{6}$. También fray Juan Bautista de Ardales escribió una extensa biografía sobre fray Isidoro que no llegó a publicar ${ }^{7}$. En las últimas décadas ha venido incrementándose de manera considerable el número de publicaciones sobre los aspectos artísticos, devocionales, de historia local y predicación sobre esta devoción sevillana ${ }^{8}$.

exequias, que la venerable hermandad de la Divina Pastora Maria Santissima [...] consagró a la buena memoria de su fundador [...] fray Isidoro de Sevilla..., Sevilla: en la imprenta de Don Juan de Basoas, [1751], y fray Nicolás de Bilbao (O. F. M. Cap.), Inmortal memoria del capuchino más peregrino..., Sevilla: en la imprenta de Joseph Padrino..., [1751].

4. Vid., entre otros trabajos, Álvaro Román Villalón, La Divina Pastora en los escritos de fray Isidoro de Sevilla, Sevilla, Gesto Sevilla Comunicación, 2012, pp. 671-867, y Cristina Gutiérrez Álvarez y Antonio Valiente Romero, «Evolución de los grabados de la Divina Pastora en Sevilla entre los siglos XVIII y XIX», Estudios franciscanos, n 106, 2005, pp. 223-236.

5. Para una aproximación biográfica a este capuchino véase Mariano de Sanlúcar (O. F. M. Cap.), «Fray Juan Bautista de Ardales, figura prócer de la provincia capuchina de Andalucía en el siglo XX», en Manuel Peláez del Rosal, (coord.), El Franciscanismo en Andalucía: conferencias del IX Curso de Verano "Los capuchinos y la Divina Pastora", Córdoba, CajaSur-Obra Social y Cultural, 2004, pp. 335-354. Fray Juan Bautista de Ardales comenzó en 1919 a planificar la creación de un Museo de la Divina Pastora en el convento de los capuchinos de Sevilla, que finalmente se inauguró en 1937. Fue autor del monumental estudio La Divina Pastora y el Beato Diego José de Cádiz, Sevilla, Imprenta de la Divina Pastora, 1949.

6. AHPCA, fray Sebastián de Ubrique, Biografia del V. P. Isidoro de Sevilla, mecanoescrito de 84 páginas.

7. AHPCA, fray Juan Bautista de Ardales, Vida del Vble. P. Isidoro de Sevilla, mecanoescrito de más de trescientas páginas. Se trata de la biografía más autorizada y completa sobre fray Isidoro de Sevilla, escrita entre 1940-1943. Un resumen de este trabajo fue publicado en La Divina Pastora y el Beato Diego José de Cádiz, op. cit.

8. De entre las más recientes caben destacar las publicaciones en revistas especializadas como El Adalidad seráfico o Estudios franciscanos, y las actas de los diez cursos de verano sobre el franciscanismo en Andalucía, entre las que destaca especialmente, Manuel Peláez del Rosal 
El estudio teológico de esta advocación fue iniciado ya por fray Mariano de Sanlúcar ${ }^{9}$ y en los últimos ańos se ha enriquecido con una tesis doctoral llevada a cabo por el padre Álvaro Román Villalón ${ }^{10}$. Por último hay que señalar el estudio y edición de La Pastora Coronada de fray Isidoro de Sevilla, que he llevado a cabo junto con Antonio Valiente Romero ${ }^{11}$.

El capuchino fray Isidoro de Sevilla vino al siglo con el nombre de Vicente Gregorio Medina Vicentelo de Leca en mayo de 1662, en el seno de una familia de la nobleza sevillana. Señala fray Juan Bautista de Ardales que el joven «cursó sus estudios en el Colegio de San Hermenegildo de Sevilla, regentado por los padres de la Compañía de Jesús» ${ }^{12}$. Posteriormente se sabe que estudió cánones y leyes en el Colegio Mayor de Maese Rodrigo en Sevilla al menos un par de años, por lo que probablemente no se graduó ${ }^{13}$.

Vicente Gregorio Medina tenía lejanos lazos de parentesco con Miguel Mańara (1627-1679), un reconocido caballero sevillano muy implicado en la actividad de la ciudad, que alcanzó el cargo de veinticuatro ${ }^{14}$. Tras la muerte de su esposa en 1661, sufrió una profunda crisis espiritual que desembocó en una total entrega a los pobres y a los desvalidos de la ciudad. Con el objetivo de dedicarse mejor a esta tarea fundó el hospital para la hermandad de la Santa Caridad de Sevilla ${ }^{15}$. Su labor fue admirada y reconocida por muchos coetáneos y su muerte originó una importante conmoción en la ciudad. Los primeros diecisiete años de vida del futuro capuchino coincidieron con la actividad piadosa de Miguel Mañara, por lo que cabe plantearse que el ejemplo de vida de este pudo ser importante para la vocación del futuro capuchino.

En abril de 1681, con tan solo diecinueve ańos y la oposición de sus padres, pues era su hijo primogénito, Vicente Gregorio Medina ingresó en el convento capuchino de las santas Justa y Rufina. Un año después concluyó su noviciado.

(coord.), El franciscanismo en Andalucía..., op. cit.

9. Vid. fray Mariano de Sanlúcar (O. F. M. Cap.), «El cristocentrismo en los escritos del V. P. Isidoro de Sevilla y su proyección sobre la devoción a la Divina Pastora», Estudios Franciscanos, $\mathrm{n}^{\circ}$ 61, 1960, pp. 63-71.

10. El padre Álvaro Román Villalón defendió su tesis titulada La Divina Pastora en los escritos de fray Isidoro de Sevilla (1662-1750) en la Pontificia Facoltà Teologica «marianum» de Roma en 2009. Ese mismo año se publicó un extracto de la investigación, que ha culminado en la voluminosa monografía: La Divina Pastora en los escritos de fray Isidoro de Sevilla, op. cit.

11. Vid. fray Isidoro de Sevilla, La Pastora Coronada, edición y estudio de Jaime Galbarro García y Antonio Valiente Romero, Sevilla, editorial Vitela, 2012.

12. Vid. fray Juan Bautista de Ardales, Vida del Vble. P. Isidoro de Sevilla, op. cit., p. 14.

13. Archivo Histórico de la Universidad de Sevilla (AHUS), libro 486, «Matrículas de cánones y leyes (1678-1717)», ff. 2v-4r.

14. Señala Antonio Valiente Romero que Miguel Mañara «era en realidad un primo lejano del padre de fray Isidoro, procedente de la línea familiar derivada del primer matrimonio de la bisabuela de este, Isabel Batallón Vicentelo, con Julio Anfriano». (Vid. Antonio Valiente Romero, "La Pastora Coronada en su contexto histórico", en fray Isidoro de Sevilla, La Pastora Coronada, op. cit., p. XXII).

15. Para el estudio de su figura es fundamental la monografía de Jesús María Granero (S. J.), Don Miguel Mañara Leca y Colona y Vicentelo (un caballero sevillano del siglo XVII), Sevilla, Artes Gráficas Salesianas, 1963. 
Posteriormente fue enviado al convento de los capuchinos de Écija, donde dedicó un año al estudio del latín. En el verano de 1683 inició su formación en filosofía en el convento de los capuchinos de Cádiz, que concluyó finalmente en el convento de San Juan Bautista de Granada ${ }^{16}$. En abril de 1687 fue ordenado sacerdote y continuó su formación durante tres años más estudiando teología como alumno del lector capuchino fray José de Lucena ${ }^{17}$. A principios de la década de 1690 fray Isidoro regresó a Cádiz, donde obtuvo el cargo de "predicador de oficio» ${ }^{18}$, y desarrolló esta actividad misionera por Andalucía occidental (Córdoba, Antequera, Marchena, Cádiz, etc.).

En esta última ciudad recibió las enseñanzas de fray Pablo de Cádiz, quien le inculcó el espíritu misionero y le instruyó en el rezo público del rosario por las calles de la ciudad ${ }^{19}$. En el capítulo provincial de la orden del 12 de enero de 1694, fray José de Lucena se convirtió en guardián del convento capuchino de las santas Justa y Rufina, y fray Isidoro volvió con él de nuevo a su ciudad natal. Para entonces su fama como predicador ya era muy reconocida.

En 1700 fue destinado nuevamente a Cádiz, donde volvió a participar en los rosarios públicos, en esta ocasión en compañía de fray Feliciano de Sevilla ${ }^{20}$. Pero el cambio de ciudad vino a coincidir con la muerte de Carlos II y el inicio de la Guerra de Sucesión. Cádiz fue, precisamente, uno de los

16. Explica fray Juan Bautista de Ardales que «ante el Definitorio Provincial, que daba su fallo en votación secreta, todo estudiante, además de los exámenes anuales, debía sufrir tres exámenes más extraordinarios: primero después del curso de Gramática, para probar su competencia y pasar al de Filosofía, que es cuando la Orden juzga que pone a un corista formalmente a los estudios; segundo, al final de la Filosofía, para entrar en la Sagrada Teología; tercero, cuando termina la carrera, para obtener del Padre General el título de predicador, sin el cual ningún hijo de San Francisco puede predicar» (Vid. fray Juan Bautista de Ardales, Vida del Vble. P. Isidoro de Sevilla, op. cit., p. 31).

17. Normalmente, los estudios duraban siete años: tres se empleaban en la filosofía y cuatro para la teología, aunque podía darse la dispensa de un año. Señala Juan Bautista de Ardales que al frente de cada grupo de coristas (en torno a cinco alumnos), el Definitorio colocaba a un lector para la dirección de sus estudios y «una vez asociados lectores y alumnos permanecían así hasta el final de los estudios, constituyendo una curiosísima parentela científica en la cual el primer Lector ocupaba el lugar del patriarca; sus discípulos, que obtenían cátedra, eran hijos, prolongadores de la estirpe; y los discípulos de estos se reputaban nietos de aquel» (Vid. fray Juan Bautista de Ardales, Vida del Vble. P. Isidoro de Sevilla, mecanoescrito, p. 30).

18. Este título le confería la capacidad de representar al convento en su labor de apostolado y, por lo tanto, era el religioso encargado de dar los sermones en las iglesias correspondientes y se le solicitaba para las grandes ocasiones.

19. El propio fray Isidoro de Sevilla evoca esta experiencia en La nube de Occidente (Cádiz: Cristóbal de Requena, 1702), biografía de su maestro fray Pablo de Cádiz, que falleció en 1694. Vid. especialmente pp. 243-250. Para el estudio del rosario como fenómeno religioso vid. José Carlos Romero Mensaque, El Rosario en Sevilla: devoción, rosarios públicos y hermandades (siglos XV-XXI), Sevilla, Ayuntamiento de Sevilla, Delegación de Fiestas Mayores, 2004; e ibid., "Fray Pablo de Cádiz, Isidoro de Sevilla y la influencia capuchina en la conformación de los rosarios», en Manuel Peláez del Rosal (coord.), El Franciscanismo en Andalucía..., op. cit., pp. 297-313.

20. Vid. Álvaro Román Villalón, La Divina Pastora..., op. cit., p. 108, n. 19, y Antonio Valiente Romero, "La Pastora Coronada en su contexto histórico», en fray Isidoro de Sevilla, $L a$ Pastora Coronada, op. cit., pp. XXXIII-XXXV. 
primeros escenarios de esta confrontación bélica, pues James Butler, II duque de Ormonde, comandando una flota anglo-holandesa puso sitio a la ciudad con el objeto de cortar las comunicaciones transoceánicas ${ }^{21}$. Los capuchinos de Cádiz, y entre ellos fray Feliciano y fray Isidoro de Sevilla, incrementaron su labor misionera con el rezo del rosario, asistieron espiritualmente a los soldados, arengaron a la tropa y, en definitiva, participaron activamente en la resistencia de la ciudad, que finalmente no fue vencida. En enero de 1703 fray Isidoro volvió a Sevilla para informar de lo sucedido en Cádiz meses antes en un nuevo capítulo provincial, en el que se decidió su regreso definitivo en la capital hispalense.

Pero Sevilla, la que antaño había sido considerada una "nueva Roma», venía sufriendo un largo proceso de declive, especialmente a partir de la peste acontecida en 1649 , en la que al menos un tercio de su población falleció. En realidad, todo ello formaba parte de la decadencia económica, política y social que arrastraba la monarquía española desde principios del Seiscientos, y que concluyó el siglo con el fin de la dinastía de los Austrias. El edificio de la Monarquía Hispánica venía acumulando tropiezos y adversidades desde entonces, como la bancarrota de 1627, el desgate de la Guerra de los Treinta Años, la independencia de Portugal en 1640, el progresivo anquilosamiento del sistema de comunicaciones marítimo-defensivo, que permitió el pillaje naval de potencias como Inglaterra en las costas peninsulares, etc. Esta zozobra se reflejó de manera inevitable en la religiosidad de finales del siglo XVII, que veía en las desgracias, en las epidemias o en las derrotas los signos de un castigo divino por haber relajado las costumbres y haber caído en el pecado.

Tal era el estado de desesperanza y pesimismo en el que vivía la población española, cuando fray Isidoro de Sevilla comenzó a organizar el rezo público del rosario por las calles de Sevilla. Así relata el capuchino en tercera persona cómo fue el primer día:

A esto aspiraba el citado predicador y, para ponerla en planta, el día 24 de junio del ańo de 1703 se fue a la iglesia parroquial del Señor San Gil de esta ciudad de Sevilla con una imagen de María Santísima, nuestra Señora, en el misterio de su Inmaculada Concepción; y habiendo juntado a alguna gente, los exhortó a que lo siguiesen cantando el rosario de la Soberana Emperatriz hasta la Alameda, donde se predicó y, agregándose a la gente, que iba otra mucha, se hizo un rosario bellísimo que se remató en [la iglesia del] Señor San Gill22.

Fray Isidoro pasó aquella noche de san Juan rezando en el coro bajo de la iglesia del convento de los capuchinos y tuvo la «ocurrencia» de representar a la Virgen con el atuendo de una pastora ${ }^{23}$. Al día siguiente visitó al pintor Miguel Alonso de Tovar y le encargó que hiciera una pintura de la Virgen tal como él la

21. Ibid., pp. XXXVI-XLI.

22. Cf. fray Isidoro de Sevilla, La Pastora Coronada, op. cit., \$.5.

23. Utilizo la expresión "ocurrencia» en el sentido lato del término y por haberlo hecho el propio fray Isidoro de Sevilla en su obra La mejor Pastora Assumpta, Sevilla, Imprenta Castellana y Latina de Diego López de Haro, 1732, \$.1406: «una mera y sencilla ocurrencia». 
imaginaba y describió poco después en La Pastora Coronada. El 8 de septiembre de 1703 fray Isidoro realizó el primer rosario presidido por la nueva imagen de la Virgen, y con el rezo de una corona franciscana, un texto que aludía ya probablemente a la Divina Pastora.

A partir de ese momento el capuchino se entregó de lleno en el desarrollo y consolidación de esta advocación. Fundó la Hermandad del Rebaño de la Divina Pastora en la iglesia de San Gil, y pronto su labor misionera franqueó la ciudad para predicar en los alrededores de Sevilla y seguir fundado hermandades dedicadas a la nueva advocación en Carmona (1706), Utrera (1707), Jerez de la Frontera (1713), Cantillana (1720), etc. Su «idea predicable» tuvo una gran aceptación no solo entre el pueblo, sino también entre los nobles (como el III marqués de la Motilla ${ }^{24}$ o, incluso, el rey. Fray Isidoro de Sevilla tomó muy pronto partido en la Guerra de Sucesión a favor de Felipe V en su estancia gaditana, y cuando la corte se instaló en Sevilla durante el Lustro Real (1729-1733) aprovechó la oportunidad para difundir su advocación entre los cortesanos y el monarca. En 1731 la familia real ingresó en la hermandad y Felipe $\mathrm{V}$ fue nombrado mayordomo y hermano mayor perpetuo de la misma ${ }^{25}$. Paradójicamente, la «ocurrencia» de fray Isidoro de Sevilla no fue bien acogida por los propios capuchinos, de hecho hasta $1742 \mathrm{el}$ provincial de la orden no aceptó que las imágenes de la Divina Pastora pudieran ser veneradas en los conventos andaluces ${ }^{26}$. No obstante, hay que señalar que contó con la ayuda de algunos de ellos, como fray Arcadio de Osuna (1640-1716), notario apostólico y procurador general de la orden, y fray Luis de Oviedo (1667-1740).

Fray Isidoro se dedicó por completo a la predicación, pero fue también cronista de la orden ${ }^{27}$, labor que quedó reflejada en el Florido andaluz pensil, una crónica capuchina escrita en dos volúmenes, en la que se da cuenta de la creación e historia de buena parte de los conventos de la provincia capuchina de Andalucía ${ }^{28}$. Pero sus obras más relevantes fueron aquellas en las que se explica su «idea predicable». En 1705 apareció La Pastora Coronada, un tratado

24. Vid. fray Isidoro de Sevilla, La Pastora Coronada, op. cit., \$.11.

25. Cf. Maribel Gómez Macías y José Joaquín Moreno Gutiérrez, «La vinculación de la Familia Real y la Primitiva Hermandad del Rebańo de la Divina Pastora en el siglo XVIII», Boletin de las cofradías de Sevilla, n. ${ }^{\circ}$ 535, 2003, pp. 635-640; y José Joaquín Moreno Gutiérrez, «La vinculación de la Familia Real y la Primitiva Real Hermandad del Rebaño de la Divina Pastora y Santa Marina (II parte)», Boletín de las cofradias de Sevilla, n 537, 2003, pp. 785791.

26. Cf. Álvaro Román Villalón, La Divina Pastora..., op. cit., p. 115.

27. Se desconoce con exactitud cuándo fue nombrado para tal cargo. La referencia más temprana se encuentra en los preliminares fechados en septiembre de 1701 de su obra La nube de occidente (1702).

28. AHPCA, lib. 555. Actualmente solo se conserva el primero de estos dos volúmenes, un manuscrito autógrafo en folio, a dos columnas, que puede fecharse hacia 1703 aproximadamente. El cronista capuchino fray Ambrosio de Valencina pudo ver los dos libros. Vid. su descripción en fray Ambrosio de Valecina (O. F. M. Cap.), Reseña histórica de la provincia capuchina de Andalucia y varones ilustres en ciencia y virtud que han florecido en ella desde su fundación hasta el presente. Sevilla, Imprenta de la Divina Pastora, 1906, tomo I, p. VIII. 
mariológico y apologético en el que expone su «idea discursiva y predicable» por la cual presenta a la Virgen con los atributos de una pastora. En 1732 se publicó La mejor Pastora Assumpta, que en buena parte era reelaboración, muy ampliada, de La Pastora Coronada. Por último hay que señalar el manuscrito del Libro segundo de la Pastora Coronada, de fecha incierta, y en el que continúa con la reflexión y argumentación de su advocación ${ }^{29}$.

A medio camino entre la crónica biográfica y la hagiografía se encuentran otras obras que abordan la vida de destacados capuchinos andaluces. Se conocen La nube del Occidente, vida y virtudes del venerable Siervo de Dios Fr. Pablo de Cádiz (Cádiz: Cristóbal de Requena, 1702), la Vida y virtudes del venerable siervo de Dios fray Francisco de Lorca (Cádiz: Pedro Gómez de Requena, 1740) y El montañés capuchino y misionario andaluz. Vida y virtudes del venerable padre fray Luis de Oviedo (Sevilla: en la imprenta de los Recientes, 1743). Constituyen tan solo una pequeña muestra hagiográfica de una producción que fue más voluminosa $^{30}$.

De igual manera el número de novenas y sermones que se conservan es muy escaso si se tiene en cuenta su intensa y dilatada labor predicadora. De las novenas y sermones que se imprimieron, generalmente por estar escritas en una ocasión especial (una festividad, una beatificación, unas exequias solemnes o fúnebres, etc.), se han localizado poco más de una docena. Destacan por su entidad algunos sermones, como El Phenix de Sevilla: Sermón del Gloriosissimo Principe de España... San Hermenegildo (En Sevilla: por Iuan Francisco Blas de Quesada, [1725]) y La fuente de las pastoras primer pastora de el mundo: sermón de la Milagrosissima imagen de María Santíssima, la primera, que en el mundo con titulo y trage de pastora... (En Sevilla: Francisco Sánchez Reciente..., [s.a.]) ${ }^{31}$.

Fray Isidoro de Sevilla falleció en el convento de los capuchinos de Sevilla el 7 de noviembre de 1750 a la edad de 89 años. Dejó escrita una vasta producción religiosa e histórica, de la que hoy solo se conserva una parte ${ }^{32}$, y contó con casi medio siglo para consolidar plenamente su advocación mariana e incluso para ver cómo su «idea predicable» se asentaba firmemente en América.

\section{LOS FUNDAMENTOS DE LA LABOR PASTORAL DE FRAY ISIDORO}

En el capítulo I de La Pastora Coronada fray Isidoro de Sevilla expone cómo fue el «origen y principio de la Hermandad del Rebaño de la Divina Pastora

29. Se conserva en el AHPCA.

30. Vid. Álvaro Román Villalón, La Divina Pastora..., op. cit., pp. 159-160.

31. Véase para una relación exhaustiva de obras de fray Isidoro de Sevilla Álvaro Román Villalón, La Divina Pastora ..., op. cit., pp. 138-160.

32. El desconocimiento sobre fray Isidoro de Sevilla ha llevado frecuentemente a confundirlo con su homónimo San Isidoro de Sevilla (556-636), y así muchos catálogos electrónicos (como el de la Biblioteca Nacional de España o la Biblioteca Virtual de Andalucía), e impresos (la bibliografía de Palau) atribuyen la obra del capuchino a este Doctor de la Iglesia. Ello dificulta más aún la identificación y localización de las obras de este fraile. 
María ${ }^{33}$. Es la primera versión de cómo sucedieron los primeros pasos de esta advocación, y el hecho de que esté realizada por su propio fundador le ha conferido de un valor casi legendario. Por esta razón hay que leer las palabras del capuchino con cierta cautela. Así, por ejemplo, en la relación de los hechos que hace se da la sensación de que todo sucedió de una forma algo espontánea: «[...] y habiendo juntado alguna gente, los exhortó a que lo siguiesen cantando el rosario [...] hasta la Alameda y, agregándose a la gente, que iba otra mucha, se hizo un rosario bellísimo [...]». Sin embargo, un predicador tan experimentado y entregado con la buena consecución de su tarea como fue fray Isidoro no iba a dejar al azar los detalles de su programa pastoral.

De hecho, lo primero que hizo tras tener su «ocurrencia» fue hacerla plasmar visualmente, y encargó entonces el mencionado cuadro de la Virgen con traje de pastora a Manuel Alonso de Tovar. Precisamente el capítulo II de La Pastora Coronada está dedicado a defender el uso de la imagen en la predicación ${ }^{34}$, y recurre a argumentos tan elocuentes como este:

No pueden todos ni saber las vidas de los santos, ni leer sus hazañosas virtudes, porque no todos saben leer, ni todos tienen tiempo para saberlas, y para que no haya alguno que sea privado de ejemplos tan admirables se le proponen las imágenes, que como asegura el capuchino Pise: Potest dici Imago plebis ignarae Liber. Y aún adelanta más su proposición diciendo que las imágenes son más poderosas para mover corazones de los hombres a seguir las virtudes que los libros más retóricos y locuaces; pues lo que no consiguen muchos eruditos libros, suele conseguirlo la simple vista de una imagen $[\ldots]^{35}$.

La cuestión de fondo que aborda aquí fray Isidoro, el uso de las imágenes en la predicación, ya había sido objeto de debate durante la Edad Media. Él mismo alude al Séptimo Sínodo, o Segundo Concilio de Nicea (787), en el que se restableció la veneración de las imágenes, entendidas estas como "prototipo" ${ }^{36}$. Como se sabe, la actitud iconoclasta desarrollada por la Reforma protestante activó nuevamente no solo la defensa de la veneración de las imágenes, sino también una nueva expresividad visual más sensual, que apela más a los sentidos que a lo intelectual, y que busca por encima de todo conmover. Nada nuevo decía fray Isidoro pues ya, por ejemplo, Francisco de Monzón en su Norte de idiotas (1563) se expresaba en términos muy semejantes: «Muchos provechos se siguen, generalmente de la vista y adoración de las imágenes, y principalmente a las personas simples y sin letras, que según se dice son sus libros, a donde leen y aprenden los hechos de aquellas personas ilustres que allí se representan $[\ldots] \aleph^{37}$.

33. Vid. fray Isidoro de Sevilla, La Pastora Coronada, op. cit., capítulo I, pp. 33-40.

34. Vid. fray Isidoro de Sevilla, La Pastora Coronada, op. cit., capítulo II: «Del culto de las sagradas imágenes y de los herejes que la han perseguido", pp. 41-54.

35. Ibid., p. 42, \$.14.

36. Ibid., p. 43, \$.16.

37. Vid. Pierre Civil, Image et dévotion dans l'Espagne du XVI siècle: le traité Norte de Ydiotas de Francisco de Monzón (1563), Paris, Presse de la Sorbonne Nouvelle..., 1995, p. 144. 
Junto a la renovación de la imagen de la Virgen, fray Isidoro introduce otra serie de modificaciones orientadas a potenciar la presentación de su nueva advocación, entre ellas está el rezo de la corona a la Divina Pastora. Fray Juan Bautista de Ardales distingue claramente entre corona y rosario, pues la corona seráfica tiene un origen franciscano, frente al rosario, que pertenece a la orden de los predicadores y fue creado por el dominico Santo Domingo de Guzmán ${ }^{38}$. Fray Isidoro crea la corona u ofrecimiento a la Divina Pastora a partir de la primigenia corona seráfica, que describe de la siguiente manera:

$[\mathrm{N}] \mathrm{o}$ es otra cosa sino cierto número de avemarías, correspondiente al número de los años que esta purísima Emperatriz vivió en este caduco y mortal siglo, el cual número es vario, como son varias las opiniones de los años que en el mundo vivió esta Señora, pero como ya prevalezca más la opinión de que fueron setenta y dos los años que vivió en este siglo de aquí es que la corona se compone de setenta y dos avemarías, interponiendo de diez en diez un paternóster. A esto se llega otro paternóster, y otra avemaría, por la intención del Pontífice, que le concedió indulgencia plenaria; con que la corona ${ }^{39}$.

Esta corona seráfica es enriquecida "con nuevas modalidades dividiendo sus misterios a la manera del rosario en gozosos, dolorosos y gloriosos y distribuyéndolos también en los días de la semana $»^{40}$. Es, en realidad, una adaptación de la corona franciscana y el rosario. Fray Isidoro amplía las tres clases de misterios del rosario (gloriosos, gozosos y dolorosos) pasando de cinco a siete, como ya tenía el septenario franciscano de los gozos, de esta manera la corona a la Divina Pastora consta de veintiún «misterios» de la Virgen. En este sentido fray Isidoro sigue de cerca a uno de sus maestros en el rosario, fray Pablo de Cádiz, y su tratado Triumpho glorioso de el Santissimo Rosario (Cádiz: en casa de Christoval de Requena, 1693) ${ }^{41}$.

A pesar de la aparente novedad que suponía la introducción de esas coplas a la Virgen en la corona seráfica, fray Isidoro estaba regresando por una parte a las raíces de su propia orden, pero por otra se adelantaba en un cuarto de siglo a los acontecimientos. Y es que en 1727 Benedicto XIII declaró en una bula que era necesario «la meditación de los misterios para poder lograr las indulgencias»" La nueva corona propuesta por el capuchino cobraba así mayor vigencia.

Tras el primer rezo público de la corona y la procesión del nuevo estandarte con la imagen de la Divina Pastora el 8 de septiembre de 1703, a fray Isidoro le faltaba un último pilar para consolidar su nueva advocación: la fundación de una hermandad. En La mejor Pastora Assumpta evoca así esta circunstancia:

38. Vid. fray Juan Bautista de Ardales, Vida del Vble. P. Isidoro de Sevilla, op. cit., capítulo XI. Bien es verdad que fray Isidoro utiliza indistintamente ambos términos en La Pastora Coronada.

39. Vid. fray Isidoro de Sevilla, La Pastora Coronada, op. cit., pp. 209-210, \$. 252; y también p. $284, \$ .359$.

40. Ibid., p. 284, \$. 359.

41. Vid. Álvaro Román Villalón, La Divina Pastora..., op. cit., pp. 627-648.

42. Vid. fray Juan Bautista de Ardales, Vida del Vble. P. Isidoro de Sevilla, op. cit., capítulo XI. Se trata de la bula Pretiosus, que ampliaba el poder de los dominicos. 
[D]eterminó el predicador fundar e instituir a la mística Pastora María una hermandad que fuese místico rebaño de corderos que, como propios suyos, la alabasen y celebrasen continuamente [...]. Para esto hizo el predicador regla propia y, aprobada por el ordinario, se dio principio a la hermandad el domingo 23 de septiembre del referido año de 1703 , celebrándose el primer cabildo en que se nombraron los oficiales convenientes, y así quedó establecida dicha hermandad del rebaño de la mística Pastora María ${ }^{43}$.

Tan solo quince días después de la primera salida de la Virgen con traje de pastora, fray Isidoro ya había conseguido reunir a un número suficiente de devotos como para fundar esta congregación. Dada la oposición que tenía dentro de su propia orden, fray Isidoro estableció esta primera hermandad en la iglesia de San Gil. Pronto hubo de modificar sus planes y en 1704 decidió trasladarse a la iglesia de santa Marina, donde había más espacio para construir una capilla a su nueva devoción ${ }^{44}$. Tras la constitución de esta hermandad fray Isidoro se empleó en la redacción de sus reglas, que ya estaban escritas y aceptadas por el primer cabildo hacia el 18 de noviembre de 1703. Finalmente, unas semanas después, el 6 de diciembre, obtuvieron la aprobación del fiscal general del arzobispado, Joseph García Platas. Fue tan solo la primera hermandad de las muchas que muy pronto el capuchino misionero fue fundando en las actuales provincias de Sevilla y Cádiz.

La imagen de la Divina Pastora, el rezo público de la corona seráfica adaptada y la fundación de hermandades dedicadas a esta devoción constituyen los tres pilares fundamentales en los que fray Isidoro basó su apostolado mariano ${ }^{45}$. En el alborear del siglo XVIII, la propuesta mariana del capuchino volvía a algunos principios de la Contrarreforma, como la reivindicación pedagógica religiosa a partir del rezo de la corona con los misterios de la Virgen, o la propuesta de una imagen mariana muy singularizada en su presentación ${ }^{46}$. Pero al mismo tiempo presentaba algunas novedades importantes, como la renovación de la corona franciscana o la propuesta de una Virgen de aspecto dulce, anińado y apacible, que nada tenía que ver con la iconografía mariana de la Virgen dolorosa que tan extendida estaba en Sevilla.

43. Vid. fray Isidoro de Sevilla, La mejor Pastora Assumpta, op. cit., p. 520.

44. Para una historia de esta hermandad vid. Juan Martínez Alcaide, Apuntes históricos y artísticos de la Primitiva Hermandad de la Divina Pastora y Santa Marina, Sevilla, Ayuntamiento de Sevilla, 2006. Hoy día la Primitiva Hermandad de la Divina Pastora y Santa Marina se encuentra en la capilla del antiguo Hospital de san Bernardo (o de los Viejos) en Sevilla, en la calle Amparo.

45. Vid. Álvaro Román Villalón, La Pastora Divina Pastora..., op. cit., p. 581.

46. Así la describe fray Isidoro: "[Ve]stida de pastora, con su pellico, cayado, y a las espaldas caído el sombrero pastoril. Está rodeada de cándidos Corderitos, todos los cuales tienen hermosísimas rosas en las bocas, ofreciéndoselas a su amantísima Pastora para tejerle con ellas una corona [...]. A lo lejos se descubre una Ovejita que, apartada del Rebaño de la Divina Pastora fue repentinamente asaltada de un león, imagen del Demonio [...], cuyo peligro reconocido de la descarriada ovejuela, para evadir riesgo tanto se valió de la dulcísima salutación del avemaría y al punto fue amparada, porque asistiéndole el señor san Miguel Arcángel, con su tajante espada la defendió del león y la redujo al Rebaño de su bellísima Pastora» (Vid. fray Isidoro de Sevilla, La Pastora Coronada, op. cit., p. 38). 


\section{El OfRECIMIENTO de LA CORONA DE MARÍA SANTísima CON TÍTULO DE PASTORA}

Como hemos visto, la corona seráfica adaptada por el capuchino es uno de los pilares fundamentales para su predicación, por esa razón debió tener desde el principio un papel destacado. Hasta ahora los documentos escritos conservados más antiguos sobre esta advocación eran La Pastora Coronada de fray Isidoro de Sevilla publicada en 1705, y la Regla, y constituciones de la Hermandad del Rebaño de la Divina Pastora... ${ }^{47}$. Pero debió existir algún impreso (o impresos) en el que los primeros fieles de esta devoción pudieron leer, cantar y memorizar la corona seráfica preparada por fray Isidoro de Sevilla. El estudio de un autógrafo desconocido hasta la fecha con el título Ofrecimiento de la Corona de María Santísima con título de Pastora aporta nuevos datos sobre esta cuestión ${ }^{48}$.

\section{IV.1 Descripción del autógrafo}

Este autógrafo es un cuadernillo cosido de 18 hojas no foliadas en su totalidad y con unas dimensiones de $21 \times 16 \mathrm{~cm}$. El papel tiene al menos tres procedencias distintas: la cubierta que sirve para la encuadernación -f.1 y f. 18-, los ff. 2-15, y los ff. 16-17. Contiene la corona franciscana en verso y en prosa escrita a la Divina Pastora por el capuchino, y coincide tanto en el contenido como en la disposición con los dos últimos capítulos de La Pastora Coronada ${ }^{49}$. Le siguen las aprobaciones y censuras originales para la imprenta. El contenido detallado de este autógrafo es el siguiente ${ }^{50}$ :

- f. 1r: Portadilla en blanco, en cuya parte superior se señala: «No 2 Ofrecimiento de la Corona de María s[antí]s[i]ma, con título de Pastora, compuesto por el M[uy] R[everendo] P[adre] Fr[ay] Ysidoro de Seuilla, con sus Censuras, y Aprobación del ordinario, originales».

- f. 1v: En blanco.

- f. 2r: Soneto que lleva por título: «Por un devoto y aficionado del auctor. Soneto, [con otra mano:] en ecos». La composición está

47. Vid. Regla, y constituciones de la Hermandad del Rebaño de la Divina Pastora María S[antí] s[i]ma y de su corona sagrada, sita en la Iglesia Parrochial del Señor S[an] Gil de esta Ciudad de Seuilla, fundada por el R[everend]o P[adre] F[ray] Isidoro de Sevilla, predicador, y Chronista de esta Prouincia de la Immaculada [sic] Concepción de N[uestr]a S[eñor]a en los Reynos de la Andaluzía de la Orde[n] de los Capuchinos. Este manuscrito fechado a finales de 1703 o principios de 1704 se encuentra actualmente en el archivo de la Primitiva Hermandad de la Divina Pastora y Santa Marina. Quiero dar las gracias a Francisco Javier Segura Márquez por facilitarme su consulta.

48. AHPCA, olim. 2 / 4/ 5. Para certificar que el autógrafo es de la mano de fray Isidoro de Sevilla se ha cotejado la letra con el Florido andaluz pensil, crónica escrita por el capuchino.

49. Vid. fray Isidoro de Sevilla, La Pastora Coronada, op. cit., pp. 283-334.

50. En la presente transcripción se ha optado por respetar la ortografía y la puntuación del original, pero se acentúan las palabras y se desarrollan las abreviaturas entre corchetes. 
dirigida a fray Isidoro, aunque el primer cuarteto, que comienza con el verso «El Alva ya con bizarría -ría» es el mismo (con alguna pequeña variante) que el del «Soneto hecho para una iusta destas Escuelas en honra del Maestro Iuan de Orduña» que aparece en los Nombres $y$ atributos de la impecable siempre Virgen María Señora Nuestra de Alonso de Bonilla, Baeça: Pedro de la Cuesta, 1624, f. 113v.

- f. 2v: En blanco.

- f. 3r: «Dedicatoria a María S[antí]s[i]ma vigilante Pastora de las Almas y digníssima Madre de Dios». El texto comienza y concluye en el recto de este folio de la siguiente manera: «A quien sino a ti amantíssima Pastora de nuestras almas se [h] auían de dirigir nuestros cariños [...] Besan tus santíssimas, e imperiales plantas Los Hermanos de tu Rebaño».

- f. 3v-4r: Palabras dirigidas «Al lector», sin firma, pero de fray Isidoro, pues hay varios fragmentos que coinciden con los $\$ .296, \$ .297$ y $\$ .298$ de La Pastora Coronada. Se trata de un texto en prosa en el que se hace una presentación encomiástica de la devoción y se habla de sus beneficios espirituales.

- f. 4v: Con disposición propia de una portadilla, y justificación centrada, aparece el siguiente rótulo: «Ofrecimiento de la Corona de María Santíssima Pastora Divina de las almas, y digníssima Madre de Dios. Dedícala a la misma Santíssima Pastora y la saca a la luz la Hermandad de su deuotíssimo rebaño, cita (sic) en la Parrochial del Señor San Gil de esta Ciudad de Seuilla».

- f. 5r [p. 1] al f. 15r [p. 19]: Considero que esta parte es el núcleo del manuscrito, pues contiene la corona a la Divina Pastora. Se encuentra paginado en la esquina superior externa, contiene reclamos en casi todas las páginas, y están rubricadas en el margen inferior por el notario apostólico Francisco Sánchez Castaño (por mandato de Juan de Monroy).

- f. 5r [p. 1]: Están tachadas concienzudamente las primeras catorce líneas del texto, siendo la lectura muy difícil porque se ha utilizado el mismo tipo de tinta. Sin embargo, como se verá, son de considerable importancia a la hora de valorar este manuscrito, pues lo tachado evidencia la existencia de un texto precedente que ya no se conserva en el cuadernillo.

En el segundo tercio del folio comienza el Ofrecimiento con el siguiente epígrafe tachado inicialmente: «EAP. $1^{0}$ - APÉNDIEE. Del modo que se [h]a de tener en cantar la Sacrosanta Corona de la Pastora divina» y tres párrafos que se corresponden con los $\$ .357, \$ .358, \$ .359$ de La Pastora Coronada. Los del manuscrito tienen una doble numeración, la primera a mano de fray Isidoro $(\$ .33, \$ .34, \$ .35)$, la segunda se distingue por un color de tinta distinto y comienza la enumeración desde el uno ${ }^{51}$. Con esta misma mano también se ha

51. En adelante señalaré esta doble enumeración mediante superíndices de la siguiente 
escrito entre la tachadura y el epígrafe transcrito: «Primera parte». La última línea del folio es el encabezamiento de los primeros poemas: «Misterios gozosos para el domingo, lunes y juebes».

- f. 5v [p. 2]: Contiene los siete «Misterios gozosos» (\$.36), presentados en dos columnas ${ }^{52}$.

- f. 6r [p. 3]: Presenta en dos columnas los «Misterios dolorosos para el Martes y Viernes» $\left(\$ .37^{5}\right)^{53}$.

- f. 6v [p. 4]: Presenta los «Misterios gloriosos para el Miércoles y Sábado» $\left(\$ .38^{6}\right)$, en dos columnas ${ }^{54}$.

- f. 7 r [p. 5]: Contiene cuatro párrafos $\left(\$ .39^{7}, \$ .40^{8}, \$ .41^{9}, \$ .42^{10}\right)$ en los que se explica cómo santo Tomás Cantuariense, guiado por una aparición de la Virgen, inició el rezo de los siete misterios gloriosos ${ }^{55}$. Al $\$ .42^{10}$ sigue un texto, tachado por una raya sencilla, que no se encuentra en La Pastora Coronada:

Pido al devoto de María Santíssima que vea el tratado que [h]e de imprimir con brevedad cuyo título es La Pastora Coronada, y allí hallará muchíssimas excelencias de María Puríssima como Pastora, [¿̨fomentos?] que enciendan en su alma la deuoción a esta Pastora divina. Hallará también muchíssimas excelencias y prerrogatiuas de la Sacratíssima Corona, y lo mucho que gana el que la reza, prouado todo con textos de la Sagrada Escriptura, y authoridades de los Santos.

- f. $7 \mathrm{v}$ [p. 6]: Encabeza la página un epígrafe semejante al del f. 5r: «EAP. Segundo Apéndice. [sobre la línea y con otra mano: "Parte segunda»] Del ofrecimiento en prosa de los Misterios de la Santíssima Corona». Desde el f. 7v hasta el f. 14r (pp. 6-19) el texto se corresponde con el último capítulo de La Pastora Coronada ${ }^{56}$. Tras un párrafo introductorio $\left(\$ .43^{11}\right)$ se inician los «Misterios gozosos para el Domingo, Lunes, y Juebes» $\left(\$ .44^{12},\left(\$ .45^{13}, \$ .46^{18(s i c)}\right)\right.$.

- f. 8 r [p. 7]: Continúan los «misterios gozosos» $\left(\$ .47^{15}, \$ .48^{16}, \$ .49^{17}\right.$, $\$ .50^{18}$.

- f. 8v [p. 8]: Concluyen los «misterios gozosos» $\left(\$ .50^{18}\right)$, reproduce el «Ofrecimiento para después de las tres avemarías» $\left(\$ .51^{19}\right)$, y comienzan los «Misterios dolorosos para el Miércoles y Viernes» $\left(\$ .52^{20}\right)$, que concluyen en el f. $9 \mathrm{v}\left(\$ .58^{26}\right)$.

- f. 9v [p. 10]: Comienza a mitad del folio el «Ofrecimiento para después de las tres Aue Marías» (\$.5927).

- f. 10r [p. 11]: Comienzan los «Misterios gloriosos para Miércoles y Sábado» $\left(\$ .60^{28}-\$ .64^{32}\right)$.

- f. 10v [p. 12]: Concluyen los «Misterios gloriosos...» $\left(\$ .64^{32}-\$ .66^{34}\right)$

manera: $\$ .33^{1}, \$ .34^{2}, \$ .35^{3}$.

52. Vid. fray Isidoro de Sevilla, La Pastora Coronada, op. cit., pp. 285-288.

53. Ibid., pp. 289-292.

54. Ibid., pp. 293-296.

55. Ibid., pp. 296-298 (\$. 360, \$. 361, \$. 362 y \$. 363).

56. Ibid., pp. 299-334. 
y comienza el «Ofrecimiento para después de las tres Aue Marías» $\left(\$ .67^{35}\right)$.

- f. $11 \mathrm{v}$ [p. 13]: Concluye $\$ .67^{35}$, y no vuelve a aparecer ninguna indicación más de párrafo. En dos columnas se dispone la «Letanía de Nuestra Señora».

- f. 11v [p. 14]: Contiene el «Oremus» tachado con rayas verticales, y los «Elogios a la Pastora Divina María Santíssima», dispuestos en dos columnas.

- f. 12r [p. 15]: En la columna de la izquierda concluyen los «Elogios...", y en la de la derecha comienzan los «Validos amorosos que dan a la Pastora María los Corderos de su rebaño», dispuestos en dos columnas.

- f. 13r [p. 17]: Concluyen los «Validos» al principio de la segunda columna y comienzan los «Siluos amorosos que da la Pastora María a los Corderos de su rebaño».

- f. 14r [p. 19]: Concluyen los «Siluos amorosos...» en la columna de la izquierda. Finaliza aquí la parte autógrafa de fray Isidoro de Sevilla de este cuadernillo. En el espacio de la columna izquierda hay tres notas escritas de distintas manos:

«Esta oración pondrá el impressor después de la letanía».

«Concede, misericors Deus, fragilitati nostrae praesidium: ut, qui sanctae Dei ginitricis memoriam agimus, intercessionis eius auxilio, a nostris iniquitatibus resurgamus per eundem Christus». Se trata del final de la antífona mariana conocida como "Ave Regina Caelorum».

«Seu[illa] y Diz[iembr]e 20 d[e] 1703. Cométtese la sensura de este papel a el Padre Joseph Zerval de la compañía de Jesús con la que se traiga». Tachado con trazos verticales.

- ff. 14v-17r: Los últimos folios recogen un conjunto de textos legales que conceden permiso para imprimir el Ofrecimiento, y que se transcriben de forma extractada a continuación:

[f. 14v] «S[evilla], Diz[iembr]e 12 de 1703. Dese liz[encia] para que se imprima con las notas del M[uy] R[everendo] $\mathrm{P}$ [adre] Ximénez. [rúbrica]».

«El D[octor] D[on] Juan de Monroy, can[ónigo] de la Santa Iglesia Metropolitana de esta ciudad de Seuilla, gou[ernador], prouisor, vic[ario] [f. 15r] g[ene] ral en ella y su Arz[obispa]do por el Ex[celentísi]mo s[eńor] d[o]n Manuel Arias [...]Por la presente doy liz[encia] para que se pueda Ymprimir este Quaderno que va escripto en nueue foxas rubricadas del presente notario q[ue] es el modo de ofrezer la Corona de n[uest] ra s[eńora], con el título de Divina Pastora, que nuevam[en]te se [h] a ynstituido y fundado en la yg[lesia] Parrochial de S[eñor] Sant Gill desta ci[uda]d. Y asimismo se compone dicho quaderno de diferentes coplas y en Alabanza de los Misterios de n[uest] ra s[eńora] y Lettanía; con tal q[ue] en donde dize os hizisteys se [h] aia de quitar, y acomodar otro verso, q[ue] no parezca que n[uest] ra s[eñora] se hizo a sí misma Madre de Dios, sino que fue hecha por Dios Madre suya; y en donde dize (colum[i b?]ino) se [h] aia de poner otra palabra q[ue] se acomode mexor a el verso; y asimismo se [h]a de quitar el verso q[ue] dize en la lettanía (sacratisime corone) y con estas notas y no de otra forma doi la dicha liz[enci]a para ymprimir dicho quaderno, dada en [f. 15v] 
Seuilla en cattorze de Diz[embr]e de mill setezienttos, y tres a[ńos]. [Rúbrica original de:] Don Juan de Monroy. Por mandado del s[eñor] P[rovisor] Francisco Sánchez Castaño.

«Dase licencia p[ara] que se imprima este quaderno de ofrecim[en] tos Sevilla y en[er] o 2 de 1704 .

[f. 16r] «Censura del M[uy] R[everendo] P[adre] Fr[ay] Francisco Ximénez del orden de predicadores, maestro en santa Theologia, que Regenta en el Colegio maior de Santo Thomas de esta Ciudad de Seuilla.

Por comissión del Señor D[on] Juan de Monroy, canónigo [...][h]e leydo con Summo gusto la regla y constituciones de la hermandad del rebaño de la Diuina Pastora María Santíssima [cruz] [añadido en el margen externo del folio: y ofrecimiento de la corona] compuesto todo y ordenado por el M[uy] R[everendo] P[adre] F[ray] Isidoro de Seuilla de los P[adres] Capuchinos, Historiador, y Predicador de su Prouincia, y vuelbo a dezir la [h]e leydo con summo gusto, y alboroço, ¿porque qué Christiano [h] abrá que no se alegre de leer las excelencias y alabanças de la que siendo reyna de los Ángeles no se desdeña, ni dedigna [sic] de Ser Pastora de los Pecadores imitando a su presiosíssimo Hijo que siendo rey de Reyes se gloria de ser buen Pastor? [...] [f. 17r] [...] Siendo pues esta Sagrada deuoción tan útil a las almas, tan eficaz para reformar las costumbres, y aplacar la ira e indignación diuina con que amenaça su Justicia, las muchas maldades que los hombres cometen será bien que V. S. dé la Aprobación q[ue] el M[uy] R[everendo] P[adre] F[ray] Isidoro de Seuilla pide por no contener cosa alguna contra nuestra santa Fee Catholica, ni buenas costumbres. Este es mi sentir saluo meliori. En el Colegio mayor de Santo Thomas de Seuilla en día 3 de Diziembre de 1703 ańos. F[ray] Francisco Ximénez, maestro y regente.

- $\quad$ ff. $17 \mathrm{v}-18 \mathrm{v}$ : En blanco.

Por último hay que señalar que a lo largo de todo el cuadernillo es posible encontrar manchas de tinta de imprenta, que se concentran de forma muy desigual, pero especialmente en los ff. $7 \mathrm{r}-13 \mathrm{v}$.

\section{IV.2 Las composiciones poéticas del Ofrecimiento}

El villancico es el metro elegido por fray Isidoro para escribir los poemas para el rezo de la corona a la Divina Pastora. La enorme variedad de modalidades que el villancico ofrecía ya en el siglo XVII le aporta la flexibilidad necesaria para sus composiciones. Así, por ejemplo, los «Elogios a la Pastora Divina» llevan una cabeza formada por una redondilla seguida de diez coplas (redondilla para la mudanza, cuatro versos de vuelta y un estribillo de dos versos). Los «Validos amorosos...» contienen una cuarteta en hexasílabos como cabeza y catorce coplas. En este caso están formadas por dos cuartetas de romancillo hexasílabo con asonancia en "é-a» y un estribillo de dos versos repetido dos veces ${ }^{57}$. Los «Silbos amorosos...» tienen la misma estructura que los «Validos amorosos...», solo que la cabeza es también un romancillo hexasílabo y tiene doce coplas.

Por último hay que señalar que los siete «misterios» (gloriosos, gozosos y

57. Los versos de este estribillo ("Veante mis ojos / y al punto me muera») han sido tradicionalmente atribuidos a Santa Teresa de Jesús. En cualquier caso son frecuentísimos en muchas composiciones religiosas y forman incluso parte de la Liturgia de las Horas. Vid. Álvaro Román Villalón, La Divina Pastora..., op. cit., p. 187 (n. 313). 
dolorosos) presentan la particularidad de no llevar cabeza, aunque luego la estructura de las coplas sea característica de un villancico: una redondilla por mudanza, un verso de enlace que rima con la mudanza, un verso de vuelta que rima con un estribillo de dos versos que se repite dos veces. Ese estribillo es el mismo en cada uno de los siete misterios gloriosos, gozosos y dolorosos: «Librad, Virgen, del Infierno / los que rezan la corona».

Como ya se ha indicado, estas composiciones se publican en los dos últimos capítulos de La Pastora Coronada. Hay que señalar que no hay variantes de consideración, más allá de que los «Silbos amorosos...» del autógrafo presentan siete coplas más que en el tratado impreso. Resulta quizás más interesante comprobar cómo los versos censurados por Juan de Monroy aparecen enmendados en La Pastora Coronada. Este canónigo de la catedral concedió una aprobación para el Ofrecimiento tras una celosa lectura y con la condición de que se corrigieran una serie de versos por no considerarlos muy ortodoxos. Esas enmiendas son las siguientes:

- "[...] en donde dize os hizisteys se [h]aia de quitar, y acomodar otro verso, q[ue] no parezca que n[uest]ra s[eñora] se hizo a sí misma Madre de Dios, sino que fue hecha por Dios Madre suya». Fray Isidoro había escrito en el «Misterio Primero. La encarnación del Verbo»: "Quando Gabriel os habló, / Y ecce ancilla respondisteis, / Madre de Dios os hicisteis / Y el Verbo en Vos encarnó». Otra mano hizo una marca al final del tercer verso y en el margen externo corrigió: «allí os visteis».

- «y en donde dize (colum[¿̨b?]ino) se [h]aia de poner otra palabra q[ue] se acomode mexor a el verso»: No he podido localizar esta corrección en todo el manuscrito, que parece más bien la enmienda estilística a un verso irregular.

- «y asimismo se [h]a de quitar el verso q[ue] dize en la lettanía (sacratisime corone)»: Efectivamente, en la «Letanía de Nuestra Señora» (f. 11r) aparece: «Regina Martirum. / Regina Confessorum. / Regina Virginum. / Regina Sanctorum omnium / Regina Sacratisima corona (sic)" y este último verso aparece tachado y con una marca a la derecha. Fray Isidoro en realidad lo que había hecho era sustituir el verso "Regina Sacratissimi Rosarii» que aparece en otras letanías a la Virgen, por "Sacratisima Corona» como una hábil forma de concederle a su personal «corona» a la Virgen la misma categoría que ya tenía desde hacía tiempo el rosario. Pero el canónigo, que podría haber omitido la lectura de un texto que a priori debía de saber de memoria, como esta conocida letanía en latín, lo leyó todo con detenimiento, advirtió el cambio de palabra introducido por fray Isidoro y lo censuró. En esta misma letanía también aparecen dos versos tachados e ilegibles entre "Mater Castisima» y "Mater Inviolata» que no se mencionan en la censura de Juan de Monroy y que necesariamente han sido eliminados por otra mano como el cambio del color de la tinta delata. 
Por último, hay que señalar que en el v. 4 del «Misterio Segundo. La huida a Egipto» (de los «Misterios dolorosos») se acumulan un par de tachaduras tanto al verso original como a una corrección que se hizo sobre él. Una anotación en el margen interno no se puede leer bien porque coincide con el cosido de la encuadernación, en cualquier caso parece que el verso tachado originalmente se mantuvo al final: «sobrada necesidad».

Los tres villancicos en elogio a la Divina Pastora fueron escritos lógicamente con posterioridad a la "ocurrencia» del capuchino, sin embargo no puede afirmarse lo mismo con respecto a los siete «misterios" gloriosos, gozosos y dolorosos. A este respecto señala fray Juan Baustista de Ardales:

Creemos que estos versos fueron anteriores a la fecha en que dio a conocer a la Divina Pastora. Basamos nuestro parecer en que desde entonces es típico en el Padre Isidoro apellidar profusamente a la Virgen con el nombre de Pastora y reducir toda la doctrina mariana a la acción de su pastorado, circunstancias que no se ven en estas letrillas. Sólo aparece una vez el título de Pastora y es en el primer misterio Glorioso que dice: «Mas alta que todo santo / y más que Spíritu todo, / sois Pastora en raro modo, / elevada al solio santo». Aquí el nombre de Pastora fácilmente pudo intercalarlo en sustitución de Señora. En cambio en los que posteriormente escribió en prosa es constante esta característica que señalamos ${ }^{58}$.

Fray Juan Bautista de Ardales hace esta observación a partir de los misterios en verso publicados en La Pastora Coronada, y en los que efectivamente solo se encuentra una mención a la Pastora.

\section{IV.3 La constitución del autógrafo}

La descripción de este manuscrito ofrece una gran cantidad de datos que hay que poner en relación tanto con el contexto socio-religioso de predicación organizado por fray Isidoro como con la información procedente de terceras fuentes como pueden ser la Regla, y constituciones de la Hermandad del Rebaño de la Divina Pastora..., La Pastora Coronada, u otros testimonios de la época. El análisis y la ordenación cronológica de esta información pueden arrojar algo de luz sobre la historia de este curioso manuscrito y, por ende, sobre los primeros pasos llevados a cabo por el capuchino en la difusión de su advocación mariana.

Resulta evidente que el núcleo original de este cuadernillo son las composiciones en verso y prosa del Ofrecimiento de fray Isidoro entre los ff. 5r14r. La huella en el papel que dejó un doblez vertical en todos los folios, así como la suciedad acumulada en la línea de este doblez en el f. 14v confirman que estos folios carecían inicialmente de los restantes.

Ahora bien, en el primer folio de este primitivo cuadernillo (f. 5 r) hay un extenso tachón que oculta un texto que debía ser la continuación de otro que le precedía. No sin gran dificultad es posible leer lo siguiente:

58. Vid. fray Juan Bautista de Ardales, Vida del Vble. P. Isidoro de Sevilla, capítulo XI, nota 7. 
[...] poder [...] Isidoro de Sevilla [...] capuchino y chronista de su religión, fundador de esta hermandad para que [...] señor provisor [...] [arz]obispado [...] la aprobación y confirmación de esta regla y [...] la iglesia del Señor San Gil [h]oy domingo diez y ocho de Nobiembre deste presente año de mil setecientos y tres.

Las escasas pero relevadoras palabras de ese tachón apuntan a que se trata del final de un libro de reglas. Y, efectivamente, en las páginas 31 y 32 de la Regla, y constituciones de la Hermandad del Rebaño de la Divina Pastora... puede leerse, tras una lista de los primeros hermanos de esta congregación, lo siguiente:

Todos los quales unánimes y conformes decimos que nos obligamos a guardar esta Regla y sus capítulos del modo que están escriptos y le damos todo nuestro poder al P [adre] Fr[ay] Isidoro de Sevilla, predicador capuchino, y chronista de su religión, fundador de esta Hermandad, para que con el Señor Prouisor Governador de esta Arçobispado alcanse la aprobación, y confirmación desta Regla, y licencia para imprimirla, y por ser esta nuestra voluntad lo declaramos assí en cabildo que para ello se [h]a justado en esta Iglesia del Señor S[an] Gil [h] oy Domingo diez y ocho de Nobiembre deste presente año de mil setecientos y tres ${ }^{59}$.

No cabe duda de que el f. $5 \mathrm{r}$ del Ofrecimiento fue inicialmente parte del final del borrador del libro de reglas de la hermandad, obra también de fray Isidoro de Sevilla.

Establecida, pues, esta estrecha relación entre los dos documentos hay que plantearse por qué razón el Ofrecimiento, con los textos en verso y prosa para el rezo de la corona, no está en el libro de reglas, como se podría esperar. En su lugar se encuentran una serie de textos legales para la aprobación, confirmación y licencia de impresión de esta regla que, como se verá, permiten establecer nuevos paralelismos y relaciones cronológicas con el manuscrito del Ofrecimiento.

En la página 32 de la Regla, y constituciones... acaba el fragmento anteriormente transcrito y comienzan dos textos legales. El primero de ellos señala lo siguiente:

Seuilla, y Nobiembre 28 de mil setecientos tres. Cométese la censura al M[uy] $\mathrm{R}$ [everendo] P [adre] Ximénez examinador synodal. Probeyolo el Señor Doctor D[on] Iuan de Monrroy, canónigo de la Santa Iglesia desta Ciudad, Gouernador Prouisor, y Vicario General en ella, y su Arçobispado en veynte y ocho de nobiembre de mil setecientos y tres ańos. Francisco Sánchez Castaño.

El segundo es la "Aprobación y censura» de fray Francisco Ximénez, fechada el 3 de diciembre de 1703, y cuyo original está en los ff. 16r-17r del Ofrecimiento. Esta aprobación se extiende hasta la página 35, donde aparece otra de don Joseph García Platas, fiscal general del arzobispado de Sevilla, fechada el 20 de noviembre de 1703. Le sigue la aprobación y confirmación definitiva de la regla firmada y fechada el 6 de diciembre de 1703 por Francisco Sánchez Castaño (por mandado del señor provisor el doctor don Juan de Monroy) en

59. Vid. Regla, y constituciones de la Hermandad del Rebaño de la Divina Pastora..., op. cit., pp. 31-32. 
las páginas 35-37. En la página 37 concluye la puesta en limpio del libro de reglas de la hermandad y el 23 de mayo de 1704 Francisco Sánchez Castaño certifica por escrito, de su puño y letra, que el traslado de la regla se ha hecho correctamente ${ }^{60}$.

La ordenación cronológica y la interpretación de estos datos, en relación con los textos legales del Ofrecimiento, permiten plantear cómo fue la gestación de este manuscrito. En primer lugar fray Isidoro de Sevilla escribió la Regla, y constituciones de la Hermandad del Rebaño de la Divina Pastora... entre el primer cabildo de la hermandad el 23 de septiembre de 1703 y el 18 de noviembre de 1703. Ese domingo los hermanos de la nueva congregación se obligan a guardar esta regla y dan permiso a fray Isidoro de Sevilla para que procure que el provisor y gobernador del arzobispado de Sevilla, el canónigo Juan de Monroy, conceda «la aprobación, y confirmación desta Regla, y licencia para imprimirla». Al día siguiente, con gran premura, fray Isidoro llevó el borrador de la nueva regla al arzobispado, donde fue leída y revisada por su fiscal general, Joseph García Platas. Este hizo algunas observaciones relativas a la organización de la hermandad, y dio su aprobación el 20 de noviembre con una serie de condiciones que debía cumplir la regla.

El 28 de noviembre, a través del notario público apostólico Francisco Sánchez Castaño, el doctor don Juan de Monroy, gobernador provisor y vicario general del arzobispado de Sevilla comisiona a fray Francisco Ximénez para que se encargue de dar la aprobación para la impresión de la obra. Así lo hace este maestro y regente del colegio de Santo Thomas, quien fecha su texto el 3 de diciembre. Su aprobación y censura para la impresión de la regla es de especial interés para el estudio de la advocación porque menciona algunas de las que él considera fuentes de la idea de la Virgen como pastora: Luis de Sotomayor (O. P.) en su obra Cantici canticorum Salomonis interpretatio (1599), Andrés Pinto Ramírez (S. I.) y Miguel de Gislerio en su Commentaria in canticum canticorum (1623). Fray Isidoro, sin embargo, no cita a ninguna de estas autoridades en La Pastora Coronada ${ }^{61}$.

Finalmente, el 6 de diciembre Juan de Monroy, representando al arzobispo de la ciudad, Manuel Arias, que estaba ausente en la corte, aprueba la regla, pero siempre que cumpla las condiciones que había establecido el fiscal Joseph García Platas. Una vez que se aprobaban las reglas de una hermandad estas eran devueltas a sus hermanos para que las pasaran a limpio. A partir de este momento pudo realizarse esta traslación, que ya estaría terminada hacia mayo de 1704, pues el 23 de ese mes una nota manuscrita de Francisco Sánchez Castańo certifica que la copia del libro de Regla, y constituciones... «esta vien y fielmentte sacada, corregida y concertada, y concuerda con su original, a que

60. Francisco Sánchez Castaño rubrica en el margen derecho de cada una de las páginas en limpio de este libro de Regla, y constituciones... Esta rúbrica es la misma que aparece en los ff. 5r$14 \mathrm{r}$ del Ofrecimiento.

61. Para el estudio exhaustivo de las fuentes de esta advocación vid. Álvaro Román Villalón, La Divina Pastora..., op. cit., pp. 307-530. 
me refiero, que para este efecto ante mi exivió el R[everen]do Padre Fr[ay] Isidoro de Sevilla [...]» (p. 35).

Ahora bien, ¿̨formaba parte de la regla de la hermandad el Ofrecimiento que hoy se conserva manuscrito? Y en caso contrario, ¿cuándo se copió el Ofrecimiento a continuación del final del borrador de la regla y por qué fray Isidoro de Sevilla lo hizo así? Son cuestiones complejas, ante las cuales solo queda plantear alguna hipótesis provisional. Que el Ofrecimiento no era parte de la regla aprobada el 18 de noviembre por los hermanos de la nueva congregación se puede deducir del hecho de que aparece en el manuscrito después del acuerdo de estos hermanos y no antes. A esto hay que sumar que en su encabezamiento original, ahora tachado, se le califica de «apéndice» y que, lógicamente, no se trasladó a la regla que se puso en limpio. En cualquier caso no cabe duda de que la fecha ante quem del autógrafo es el 12 de diciembre de 1703, pues esa es la primera anotación legal para su impresión tal como aparece en el f. 14v. Pero, ¿̨por qué fray Isidoro copió el Ofrecimiento justo después del final del borrador del libro de regla que ya había sido aprobado? Quizás hay que buscar la explicación en la doble naturaleza que presenta este borrador, pues si por una parte se trataba de la regla que se sometía a la aprobación del arzobispado, al mismo tiempo era un texto para el que se solicitaba permiso para imprimir ${ }^{62}$. De esta manera cabe la posibilidad de que la impresión de la Regla, y constituciones... llevara incluida al final, como dos capítulos anexos, el Ofrecimiento, y que la copia en limpio de la regla cotejada finalmente en mayo de 1704 no tuviera que llevar este texto. No obstante, de la impresión de esta Regla, y constituciones... no se tiene ninguna noticia bibliográfica, por lo que no hay que descartar que no llegara a hacerse. Si se imprimió cabe pensar que se hizo después de su puesta en limpio en el libro de reglas de la hermandad, es decir, con posterioridad a mayo de 1704. Sin embargo, el manuscrito del Ofrecimiento viene acompañado, como ya se ha visto, de otros textos legales que evidencian que fue impreso en enero de 1704.

Así, pues, fray Isidoro de Sevilla, tras la aprobación de la regla el 6 de diciembre preparó el manuscrito del Ofrecimiento para pedir su impresión. Como ya se ha descrito, en el f. $14 \mathrm{v}$ se encuentra una escueta anotación que da permiso para imprimir: «S[evilla], Diz[iembr]e 12 de 1703. Dese liz[encia] para que se imprima con las notas del M[uy] R[everendo] P[adre] Ximénez». Estas notas aluden probablemente a la "Censura del M[uy] R[everendo] P[adre] Fr[ay] Francisco Ximénez», cuyo original aparece al final del Ofrecimiento, en un tipo de papel distinto al anterior, en los ff. 16r-17r, y que inicialmente había sido realizada para aprobar la impresión de la regla de la hermandad. Se trata de un claro ejemplo de reutilización de una aprobación para un texto distinto del que estaba destinado. En esta ocasión la lectura atenta de la aprobación original inserta al final del Ofrecimiento lo corrobora, pues junto al texto que dice "[h]e

62. Como ya se ha transcrito más arriba, en la p. 32 de la Regla, y constituciones... señala expresamente: «[...] le damos todo nuestro poder al P[adre] Fr[ay] Isidoro de Sevilla, [...] para que con el Señor Prouisor Governador de esta Arçobispado alcanse la aprobación, y confirmación desta Regla, y licencia para imprimirla». 
leydo con Summo gusto la regla y constituciones de la hermandad del rebaño de la Diuina Pastora María Santíssima [cruz] compuesto» una mano distinta ańadió al margen: «[cruz] y ofrecimiento de la corona» ${ }^{63}$. De esta manera fue cómo la censura para la impresión de la regla acabó sirviendo también para la impresión del Ofrecimiento.

No fue suficiente para las autoridades eclesiásticas la censura de Francisco Ximénez, y el 14 de diciembre Juan de Monroy concede una nueva aprobación al Ofrecimiento, como ya se ha comentado anteriormente. Una nota en el f. $14 \mathrm{r}$ indica que hubo la intención de pedir una nueva censura: «Seu[illa] y Diz[iembr]e 20 d[e] 1703. Cométtese la sensura de este papel a el Padre Joseph Zerval de la compañía de Jesús con la que se traiga». Sin embargo, esa nota está tachada y no se tiene evidencia de la existencia de esta aprobación, por lo que podría suponerse que finalmente no se llevó a cabo. En cualquier caso, muy pocos días después, el 2 de enero de 1704 el texto conseguía la licencia para ser impreso tal como se señala en el f. 15v: «Dase licencia p[ara] que se imprima este quaderno de ofrecim[en]tos. Sevilla y en[er]o 2 de 1704».

\section{IV.4 Del autógrafo a la imprenta}

De la descripción y análisis del autógrafo isidoriano se deduce que el Ofrecimiento acabó en la imprenta, algo que otros testimonios de la época avalan, como El Apóstol Mariano de Heraclio de Villegas ${ }^{64}$. Ahora bien, es necesario indagar en la naturaleza de los impresos que salieron del autógrafo, pues todo hace indicar que apareció más de uno con los versos para rezar la corona.

En primer lugar hay que recordar la posibilidad de que los misterios en verso y prosa del Ofrecimiento aparecieran como apéndices en la impresión de la Regla, y constituciones de la Hermandad del Rebaño de la Divina Pastora..., aunque como ya se ha señalado hay dudas sobre la existencia de este impreso. En cualquier caso, para el programa de predicación de fray Isidoro de Sevilla, lo importante no era tanto la Regla, y constituciones..., sino el Ofrecimiento. La prueba de ello es que casi al mismo tiempo que gestionaba la aprobación y el permiso de impresión de la Reglas, y constituciones..., consiguió la licencia el 2 de enero de 1704 para imprimir el "Quaderno que va escripto en nueue foxas rubricadas» ${ }^{65}$. Fray Isidoro no tardaría en llevarlo a la imprenta para facilitar así a los devotos un opúsculo en el que poder leer y cantar la corona a la Divina Pastora. Este primer impreso del Ofrecimiento apareció probablemente en enero o febrero de 1704, y su contenido debió de limitarse únicamente a lo que he denominado núcleo del cuadernillo, es decir, los ff. 5r-14r. Además, si se

63. Este añadido al margen no está, lógicamente, en el traslado en limpio de la Regla, y constituciones...

64. Vid. Heraclio de Villegas, El Apóstol Mariano, op. cit., bifolio 26.

65. En realidad son 10 folios rubricados todos en el margen inferior del recto desde el $\mathrm{f}$. $5 \mathrm{r}$ hasta el f. $14 \mathrm{r}$. 
tienen en cuenta las características más habituales en la producción de impresos religiosos breves de carácter popular a principios del siglo XVIII, el Ofrecimiento apareció muy probablemente en formato $8^{\circ}$, con unos tres o cuatro pliegos, $\mathrm{y}$ sin la censura de fray Francisco Ximénez.

Esta primera impresión habría solucionado, al menos por el momento, las necesidades que fray Isidoro tenía para la predicación y difusión de su advocación. Los «misterios» en verso del Ofrecimiento podían ahora ser cantados en el rezo público de la corona de la Divina Pastora que el fraile siguió organizando durante esos meses. $\mathrm{Al}$ mismo tiempo los «misterios» en prosa, que él había escrito con la finalidad de ser leídos en un ámbito privado, le permitirían llegar, hasta cierto punto, a aquellos devotos que por diversas razones no podían salir en procesión en el rezo de la corona. Hay que tener en cuenta dos factores que obstaculizarían su predicación en este sentido, por una parte el alto índice de analfabetismo del pueblo, que no podría leer en casa el Ofrecimiento pero sí oírlo y memorizarlo si salían a cantarlo; y por otra parte la prohibición expresa de que las mujeres participaran en dicho rezo público. Así había sido dispuesto por Joseph García Platas, fiscal general del arzobispado de Sevilla, y refrendado por Juan de Monroy en las aprobaciones a la Regla, y constituciones...: «Y en la Corona que saliere por las calles de esta hermandad no $[\mathrm{h}]$ an de ir Mugeres algunas aunque sean hermanas, pues con esto se ebitan muchos inco[m]benientes» ${ }^{66}$.

Poco después de la primera impresión debió de producirse una segunda, en la que el Ofrecimiento se publicó ya de una forma más cuidada y fue costeado por la propia Hermandad del Rebańo de la Divina Pastora. En esta ocasión el núcleo del Ofrecimiento fue acompañado de los preliminares que hoy le preceden en el autógrafo (ff. 2r-4v), es decir, de una portadilla (f. 4v), de la "Dedicatoria a María Santísima...» (f. 3r), de las palabras "Al lector» de fray Isidoro de Sevilla, tal vez del soneto de un devoto y aficionado (f. 2r), y de la censura del maestro y regidor Francisco Ximénez. También sería probable que llevara un grabado de la Divina Pastora en los términos iconográficos que fray Isidoro había establecido, pues ya se ha visto cómo la imagen era un pilar fundamental en la predicación del capuchino. Este debió de ser también un impreso en $8^{\circ}$ de mayor extensión que el anterior y probablemente con una tirada más significativa. No obstante, esta es solo la reconstrucción hipotética de un impreso de 1704 que, por ahora, no he localizado en ninguna biblioteca o archivo, pero del que no hay duda de que existió. Además de la alusión que hace Heraclio de Villegas en 1751, hay una mención inequívoca en un pleito abierto por los hermanos del Rebaño de santa Marina a los de san Lorenzo, por haber colocado en su iglesia una imagen de la Virgen María con el título de

66. Vid. Regla, y constituciones de la Hermandad del Rebaño de la Divina Pastora..., p. 35. De hecho, cuando en 1735 fray Pedro Vázquez Tinoco (O. P.) inició los rosarios públicos de mujeres, fray Isidoro de Sevilla no tardó en seguirle y fundar, asociada a las respectivas hermandades, congregaciones de mujeres para el rezo de la corona (Vid. fray Juan Bautista de Ardales, La Divina Pastora..., op. cit., pp. 69-70, y Álvaro Román Villalón, La Divina Pastora..., op. cit., p. 647). 
Pastora, y en él se alude al Ofrecimiento en los siguientes términos:

De la hermosa Raquel dize el P. M. Fr. Francisco Ximénez, Regente de Santo Thomas, en la Censura que en 3 de Diziembre del año de 1703 dio a el Librito que imprimió la Hermandad de la Pastora y Rebaño, sita en la Parroquial de señor San Gil, dedicado a la misma Señora, con el título de Pastora Divina de las almas, con el 28 del Génesis, y el Doctíssimo Sotomayor en el I de los Cant. Y con Gislerio, que venía con su manada, y con la de su padre $[\ldots]^{67}$.

Este manuscrito contiene, por tanto, evidencias de haber servido al menos para imprimir estos dos opúsculos, que si bien ofrecían el mismo contenido en lo que a la predicación se refiere, desde el punto de vista material presentaban resultados distintos. No obstante, por estos años se debieron de imprimir más pliegos de características similares, pues fray Isidoro de Sevilla no tardó en continuar su predicación por villas y pueblos cercanos a Sevilla. Uno de estos primeros impresos fue tal vez el Ofrecimiento de la Corona de María Santíssima, Nuestra Señora, con el apreciable Titulo de Pastora Misionera (s.l.: s.n., s.a.), de 40 páginas $^{68}$. Álvaro Román Villalón considera que "probablemente» fue impreso en 1703, sin embargo, a la luz de lo que vengo exponiendo en este trabajo, ese pliego es sin duda algunos años posterior ${ }^{69}$. Este Ofrecimiento de la... Pastora Misionera coincide en gran medida con el Ofrecimiento manuscrito y con el que aparece al final de La Pastora Coronada, pero presenta algunos cambios de importancia. Para empezar carece de los «misterios» en prosa, y aunque lleva la letanía, los «Elogios a la Pastora...», los «Validos amorosos...» y los «Silvos amorosos...», concluye con composiciones que ya no están en $\mathrm{La}$ Pastora Coronada (ni en el Ofrecimiento manuscrito), como unas "Coplas a la Pastora Misionera...", unos "Silvos amorosos... para que oygan la Misión», y una «Salve». Además, el título de "Pastora Misionera» no se emplea en $L a$ Pastora Coronada (1705), pero sí muchos años después en La mejor Pastora Assumpta (1732). Por todo ello considero que este impreso debe de ser como muy pronto de finales de 1705 o 1706, pues fray Isidoro de Sevilla no terminó de asentar a la Hermandad del Rebaño de la Divina Pastora hasta octubre de 1705, fecha en la que consiguió que se instalara en la iglesia de Santa Marina. A partir de ese momento el capuchino pudo comenzar su labor misionera con la Divina Pastora en sentido estricto, y en 1706 ya fundó una nueva congregación en Carmona. Es a partir de ese momento cuando considero que cobra pleno sentido el título de «Pastora Misionera».

67. Vid. Diego Juan de Lugo y Arrieta, Validos politico-jurídico-sacros, por la colocación de María S[antí]s[i]ma con el título de Pastora, en la Iglesia de S[eño]r S[an] Lorenzo, en el pleyto con los hermanos de la misma advocación, en S[eño]ra Santa Marina; sobre que no se permita; y demás que consta de los Autos. Pruébase, no ser prohibido [h]aver dos Imágenes de un mismo título, ni la pluralidad de Hermandades de una misma Advocación en Ciudad Populosa, oc. (s.l.: s.n., s.a) [Sevilla: ca. 1712-1720]. Ejemplar consultado en el Archivo Capitular de la Catedral de Sevilla, Sección VII: Justicia, subsección: Pleitos, libro 10868.

68. Se encuentra en la Biblioteca Arzobispal de Sevilla, caja 5/22.

69. Vid. Álvaro Román Villalón, La Divina Pastora..., op. cit., p. 139 y pp. 584-615. 
Al menos estos dos impresos se hicieron a partir del autógrafo del Ofrecimiento pero no se puede descartar que facilitara otras impresiones con posterioridad. De hecho, el manuscrito presenta algún detalle que, en mi opinión, apunta en esta dirección. Por ejemplo, existen dos tachones realizados por dos manos distintas, como ya se ha descrito en los ff. $7 \mathrm{r}$ y $11 \mathrm{v}$, que evidencian la existencia de otras fases posteriores en las que el manuscrito fue utilizado para imprimir el texto.

$\mathrm{Y}$ es que no cabe duda de que el cuadernillo del Ofrecimiento presenta evidencias indiscutibles de que estuvo en una imprenta, como las manchas dactilares de tinta en muchos de sus folios, o la elocuente nota en el f. 14r: «Esta oración pondrá el impressor después de la letanía». Además, hay diez folios rubricados en el margen inferior por Francisco Sánchez Castaño, los párrafos presentan una doble numeración, y el autógrafo está acompañado de las aprobaciones legales y las referencias a este ejercicio, así como los preliminares (la dedicatoria o las palabras al lector). Todos estos detalles son característicos de un "original de imprenta», ahora bien, ¿son suficientes para afirmar que tal es la naturaleza del Ofrecimiento? No es fácil esclarecer esta cuestión, porque de entrada carecemos de los datos fundamentales para aplicar los dos procedimientos básicos que permitirían establecer que estamos ante un "original de imprenta», es decir, "seguir las distintas operaciones a través de marcas externas al texto, que dejan su constancia en el manuscrito, y el cotejo de éste con el impreso correspondiente ${ }^{70}$. Como ya se ha visto, no sé conoce el impreso (o impresos) a que dio lugar este manuscrito y, además, el texto carece de las marcas propias de un «original de imprenta» como las anotaciones en los márgenes que contienen combinaciones de números y letras en relación a las planas en las que se constituye el impreso, el trazo de estimación, el trazo de corte, los trazos de cuenta, las cabeceras, etc. ${ }^{71}$ Sonia Garza ha puesto de manifiesto que "pocas veces un original de imprenta resulta haber sido manuscrito por el autor mismo ${ }^{72}$. Añade Pablo Andrés Escarpa que «son también indicio de original para la imprenta las manchas de tinta con las huellas de los dedos del componedor $\aleph^{73}$, indicio, pero no prueba, porque lo habitual es encontrarlas en los márgenes del texto, y no de manera generalizada sobre el propio texto, como se observa en el Ofrecimiento... En definitiva, no encuentro suficientes argumentos para poder afirmar que el Ofrecimiento es un «original de imprenta».

Probablemente el autógrafo de fray Isidoro dejó de ser necesario cuando ya se habían impreso varios pliegos con el Ofrecimiento y cuando dos años después apareció La Pastora Coronada. En realidad este tratado se retrasó en su

70. Vid. Pablo Andrés Escarpa, «El original de imprenta», en Francisco Rico (dir.), Imprenta y crítica textual en el Siglo de Oro, Valladolid, Universidad de Valladolid, 2000, p. 30.

71. Vid. Sonia Garza, «La cuenta del original», en Francisco Rico (dir.), Imprenta y crítica textual..., op. cit., pp. 75-77.

72. Ibid., p. 65.

73. Vid. Pablo Andrés Escarpa, "El original de imprenta», en Francisco Rico (dir.), Imprenta $y$ critica textual..., op. cit., p. 30 . 
impresión más de lo que esperaba el propio fray Isidoro. Él era consciente desde el principio de los riesgos que conllevaba proponer una imagen renovada de la Virgen María con el traje de pastora, por esa razón había ya previsto muchos de los obstáculos con los que se iba a encontrar. El primero de ellos era, sin duda, su propia orden, por esa razón preparó este tratado en el que argumentaba en qué consistía la nueva advocación. Viene siendo lugar común señalar que $L a$ Pastora Coronada fue una respuesta a las críticas surgidas en el seno de la orden y en la iglesia sevillana, pero lo cierto es que fray Isidoro ya tenía prácticamente escrita su obra en noviembre de 1703, tan solo dos meses después de iniciar la predicación bajo el estandarte de la Divina Pastora. La coincidencia de algunos fragmentos de su tratado con el libro de Regla, y constituciones... ya lo pone de manifiesto, pero de forma más explícita lo deja claro en el $\mathrm{f} .7 \mathrm{r}$ del Ofrecimiento: «el tratado que [h] e de imprimir con brevedad cuyo título es $L a$ Pastora Coronada». Para entonces la obra probablemente ya estaba en mano de dos frailes teólogos de la orden que concedieron su aprobación el 22 de enero de 1704. Sin embargo, la publicación de La Pastora Coronada se retrasó hasta octubre de $1705 \ldots$ y mientras tanto fray Isidoro aprovechó para seguir ampliándola ${ }^{74}$.

\section{Conclusión}

El interés del Ofrecimiento de fray Isidoro de Sevilla reside en su singular formación como manuscrito poético y religioso. La reutilización que se ha hecho de este autógrafo pone en evidencia las complejas relaciones que pueden llegar a establecerse entre distintos testimonios destinados a la predicación y a la consolidación de una advocación mariana. La más significativa de ellas es su peculiar vinculación con un documento de naturaleza tan singular como las reglas de una hermandad, con el que comparte una censura para la impresión. Además, sin llegar a ser un "original de imprenta», el Ofrecimiento mantiene un estrecho diálogo con el taller del impresor, pues fray Isidoro lo utiliza una y otra vez como su copia personal. La interpretación del riquísimo conjunto de datos derivados de este autógrafo permite reconstruir no solo las acciones llevadas a cabo por este capuchino para la predicación y la implantación de su advocación religiosa, sino también las características que pudieron tener dos pliegos poéticos hoy perdidos fechables en torno a 1704 en Sevilla. Si el Ofrecimiento se conservó no fue porque su contenido fuera exclusivo, después de diversas impresiones, sino porque el propio fray Isidoro de Sevilla lo acabó considerando una especie de reliquia personal de su «sencilla ocurrencia».

74. Para un comentario más detenido sobre los avatares de la publicación de esta obra vid. fray Isidoro de Sevilla, La Pastora Coronada..., op. cit., pp. LXVII-LXXVIII. 